\title{
INVESTIGATION OF ROLLING AS A SeCondary Soil Cultivation Process
}

\author{
MurseC, B.; JANZEKOVIC, M. \& BANAJ, D.
}

Abstract: Rolling removes the deficiencies committed during ploughing. In a field test the influence of different rollers (edged, rubber and smooth) on sprouting of three sorts of buckwheat ('Bamby', 'Darja' and 'Gorenjka') was compared. The test was carried out on the basis of divided lots of land in a random block. Sowing and rolling were performed on 6 June 2003. Then, there was an extreme drought causing lack of humidity in the ground. The plants were counted on the 10 and 12 July, i.e., on the fourth and sixth day after sowing. The most sprouting plants were in case of rubber rollers, followed by smooth and edged rollers. The least plants sprouted on the non-rolled lots of land. The sort had a statistically characteristics effect on the share of plants sprouting during the fourth and sixth day after sowing. The sort 'Gorenjka' had most sprouting plants, followed by the sort 'Bamby' and the sort 'Darja' with least sprouting plants. The most favourable combination is the rubber roller and the sort 'Gorenjka'. Rolling is an important soil cultivation measure after sowing of small seed such as the buckwheat seed, particularly, during the time of drought when the test was performed.

Key words: Rolling, secondary soil cultivation, field test, sprouting, buckwheat
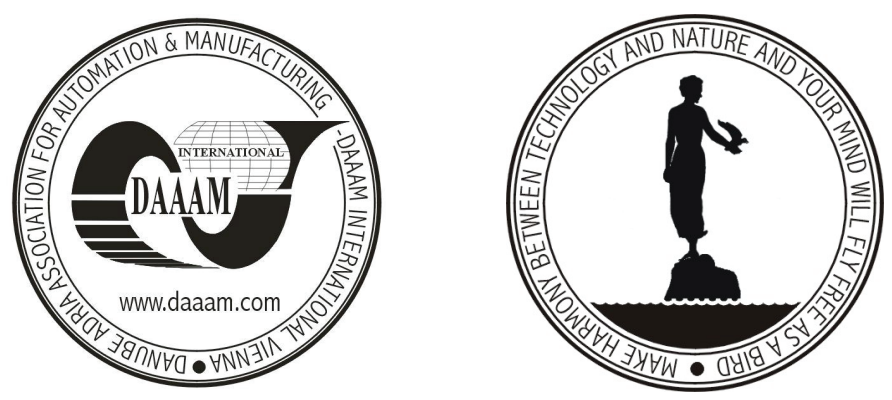

Authors' data: Assoc. Prof. Mursec B.[ogomir]*, Asst. Prof. Janzekovic M.[arjan]*, Full Prof. Banaj D.[uro]**, *University of Maribor, Faculty of Agriculture, Slovenia, **University of Osijek, Faculty of Agriculture, Croatia, bogomir.mursec@uni-mb.si,marjan.janzekovic@uni-mb.si,djbanaj@pfos.hr

This Publication has to be referred as: Mursec, B.; Janzekovic, M. \& Banaj, D. (2006). Investigation of rolling as a Secondary Soil Cultivation Process, Chapter 34 in DAAAM International Scientific Book 2006, B. Katalinic (Ed.), Published by DAAAM International, ISBN 3-901509-47-X, ISSN 1726-9687, Vienna, Austria DOI: $10.2507 /$ daaam.scibook.2006.34 